\title{
N-Acetyl Glucosamide Measurement
}

National Cancer Institute

\section{Source}

National Cancer Institute. N-Acetyl Glucosamide Measurement. NCI Thesaurus. Code C79459.

The determination of the amount of $\mathrm{N}$-acetyl glucosamide present in a sample. 